\title{
Multiple Variable Social Distancing Model in Reducing COVID 19 Spreading: A Long Term Social Distancing Model in Developing Nations Like Bangladesh
}

\author{
Md Shumon Zihady ${ }^{1,2}$ \\ ${ }^{1}$ MPA, University of Exeter, UK \\ ${ }^{2}$ Senior Assistant Secretary, Ministry of Public Administration, Government of Bangladesh, Bangladesh \\ Correspondence: Md Shumon Zihady, Senior Assistant Secretary, Ministry of Public Administration, Government \\ of Bangladesh, Bangladesh. E-mail: shahosro210.shumon@gmail.com
}

\author{
Received: August 28, 2021 Accepted: October 3, $2021 \quad$ Online Published: October 5, 2021 \\ doi:10.5539/par.v10n2p66 URL: http://dx.doi.org/10.5539/par.v10n2p66
}

\begin{abstract}
Covid-19 pandemic requires strong and inclusive social distancing policies for the people. Governments around the world have taken policy steps and citizen were expected to behave accordingly. However, Countries like Bangladesh faced enormous difficulties and challenges to make people understand and obey them. There is variety of groups in the society among whom a few were respectful and some were negligent towards those social distancing policies. This study tried to find what makes them obey or disobey the prescribed pandemic behavior. This research found people over-confident, religiously blind, economically bound, poorly educated, doubtful to their government, impatient about the time frame of the lockdown and social distancing rules and so on. Additionally, sometimes government policies were proved to be incompatible with the rising situation. Primary hypothesis of this study is, "willingness of social distancing is a dependent variable where over-confidence, education, poverty, religion, public trusts are independent variables. Taking general policies like other natural disaster or calamities may not be as effective as it was before." This pandemic is an event which needs an in-depth research, wider policy analysis and firm implementation. Here is a suggestion called 'multiple variable social distancing model' which will study about the variables first and guide to a wider policy structure afterwards.
\end{abstract}

Keywords: multiple-variable, social distancing, pandemic, local government, policy

\section{Introduction}

Until we can ensure our people get vaccinated with an effective, successful and long term immunity vaccine, social distancing is the best practice to prevent the spreading of the disease at least until 2022 (Kissler et al, 2020). Social distancing is a behavioral response that has been proved to be effective as a non-pharmaceutical treatment to the contagious disease from the experience of influenza pandemic in 1918 (Yu, lin, chiu and he, 2017). In other words, social distancing means limiting school-colleges-universities, cutting public events, social mixing, transports and others (Smith and freedman, 2020). It requests people to maintain a minimum distance during social transactions, service exchange and other community meetings which may slow down the traditional service providing rate and reduce quality.

However, this study was not aimed to focus on the effect or necessity of social distancing. Rather, it attempted to find the answer regarding how local administration and government can enhance the willingness of social distancing among people. Why people obey or disobey social distancing policy taken by the government? Social distancing is a behavioral measure which needs governmental and social intervention all together; it requires a behavioral and cognitive policy design by the central and local government simultaneously to make a change in public attitude. Hence, this paper investigated what measures the local government of Bangladesh has been initiating to ensure social distancing and how it can boost up willingness of social distancing among people in future days.

\section{Rationale}

Since Bangladesh, India and Pakistan and other south Asian countries have some similarities in governance, legacy and management system, it can be said that a ubiquitous model can be applicable for ensuring social distancing in 
Bangladesh and other south Asian countries which have similar demographic and administrative features. As said earlier, social distancing is a set of behavior which makes people follow some social norms by which they can reduce physical contact and control the spread of the virus. People follow those norms depending on their cognitive capacity and decision-making skills because the decision of social distancing relies on economy, public trust, healthcare facility, religious values and other factors. These factors are not equally influential in every country or all the time. These can vary in different contexts. This paper, therefore, elaborated how these variables could impact on a dependent variable called willingness of social distancing. The willingness of social distancing changes with the change of those factors which can be called independent variables. Before going into detail, we need to discuss what is meant by social distancing and willingness of social distancing. After that it is important to clarify how willingness of social distancing is related to those factors with evidence and examples. Newspapers and journals provided us with some evidences and reports which show that people breach social distancing norms under some particular situation in different countries. People have choice-conflict among them, whether to maintain that monotonous social distancing, or to risk themselves of being affected and lead a traditional life. Contagious diseases have these behavioral dilemmas which are called choice conflict (Kozlowski et al, 2010).

Motive of the argument of this paper is to suggest a model which will deal with a context-based factor and will be able to solve the problems working behind the willingness of social distancing. We have to be prepared for another shock, wave of series of health disaster in future. Behavioral solutions are proved sustainable and effective where pharmaceutical answer is not available or sufficient. Governments have to think about a long-term social distancing policy and take necessary actions depending on those factors responsible to provoke people to violate norms. 'Multiple variable social distancing model' can be a guideline for countries like Bangladesh to produce a sustainable social distancing policy.

\section{Review of Literature}

Olsen and Hjorth (2020) in their research work found that, in Denmark older and educated people are more willing to government policies on lockdown, social distancing, quarantine and so on. Less educated and younger people more often tend to disobey the laws. They breach social distancing norms than any other community does. It depicted a clear picture that education and age play crucial roles behind this policy practice. Governments around the world are suggesting social distancing as a probable solution and they all are facing different kind of challenges with their citizens to ensure it.

Countries like Bangladesh suffer from lack of public trust due to corruption, nepotism and malpractice of political power. Researchers showed that public trust is considerably significant to fight pandemic together because it is a battle of the community where everyone is a soldier. Due to corruption in relief management, procurement of medical instrument and other staffs people struggle to believe in their government and its initiatives.

This is a global scenario too, as we have evidences of corruptions around the world. Local government needs trust, legitimacy and enough budgetary strength. Local health departments in many countries have been proved to be very weak economically in this time (Rebekka et al, 2019). Professor Edward French (2011) argues that the legitimacy of local government in some states of the United States have helped them take better policy than those states who did not work with proper credibility.

Local government's activeness is very crucial, early experiences proved. Bangladesh is a highly centralized and unitary form of government. Oxford government response tracker is a team who is working on the role of different government units during pandemic like Ebola and COVID-19. They mentioned that West Africa found that central initiative during Ebola was not that successful until the local leaders played their role accordingly. This public sector governance team suggested five lessons for local governments around the world. These are: "Eliminate institutional overlaps, Encourage emergency preparedness, Enhance integration, Empower citizens, and Everyday resilience." (PSGT,2020). Some veteran Bangladeshi political leaders urged that government has prioritized the bureaucrats more than political leaders and representatives of the people. Newspapers reported "In the time of COVID, bureaucrats are doing the job of people's representatives, said Workers Party President Rashed Khan Menon, But at the end of the day, politicians have to face all the criticism." (Bhattacharjee, 2021)

Political belief can even change an individual's behavior. Painter and Qui (2020) conducted a research and they mentioned social distancing is a behavior which is influenced by a number of factors. They collected data on political beliefs from USA and found that in different states in USA democrats are less likely to maintain the statelevel orders if those are issued by a republican mayor. This is so vivid that, political views of citizens can even influence citizen's behavior evolving the social distancing policy. They concluded that both or all the parties should contribute to willingness of social distancing. This idea helps us understand political scenario of our country because there are some party activists who opposes the government initiative just because they are in the opposition 
party. They see everything more critically and more offensively than others.

This study resorted to plethora of news reports and news feature which enriched it with updated information from authentic sources. Aljazeera, the Daily star, daily sun, New York times are the newspapers supported most. Aljazeera has a section called 'Asia' which provided us with corona virus update and pandemic condition in Asian countries. Daily star is a leading newspaper from Bangladesh which publishes authentic data about the situation and government response towards COVID-19. It helped secondary data collection about government initiative and public responses. Other newspapers contributed to this work in such manner. Surfing on quite a good number of journals like American psychological association, Elsevier, research gate, Public administration research were important parts of the research too.

News and media while their telecast, showed that enormous people are saying that they are not going to be affected by Corona virus because they are pious, young and good people. They stated all those words in front of live cameras. This work took privilege to study over some article on 'over confidence' because in the multiple variable social distancing model it is mentioned that confidence level is a factor which let us obey or disobey the social distancing rules. Berner and Graber (2008) have written a very articulated piece of paper about the over-confidence and decision-making error. Though that was specifically for medical people like doctors or dialogists, it helped this paper to understand how choice structure is affected by over-confidence. Enormous people in Bangladesh think they are not going to be affected because they live in a warm country, or they trust in God, or they have immunity. This may be an example of over-confidence, confidence without ground. To enhance social distancing, we must pull in the reins of over-confidence. To establish the argument, It was needed to take help from some literature that provide us some insights about how the social distancing is working in different countries around the world; Such as Italy, china, Singapore. Briscese (2020) has worked hard on social distancing compliance in Italy. We learned how willingness of social distancing is related to duration and expectations. Briscese (2020) and his colleagues nicely introduced those factors which are primarily responsible for willingness of social distancing in Italy but he mainly focused on expectation and duration of social distancing program. During primary data collection Questionnaire was set to find out the confidence level of the respondents too. A considerable number of respondents think that Corona virus is not going to affect them because they obey their Gods, or they are young enough to fight that virus.

Both primary and secondary data have been collected on religious misinterpretation and its influence over pandemic behavior and public gatherings violating social distancing norms from some web sites and news portals. Additionally, these sources look into the relief activities of local government bodies and their corruption. These news and reports facilitated our understanding on relation among corruption, public trust, over confidence and willingness of social distancing. Beside theses, some articles written specifically on social distancing in Bangladesh contributed to reach results. One of the most discussed articles on Bangladesh's role in tackling COVID-19 is "tackling the COVID-19: Bangladesh perspective" by Taimur, talukdar, Siddique and mofazzal (2020). They demonstrated what the initial action has been taken by the government and whether they are enough or not. It discussed the testing capacity, poor health system, lack of public awareness, economic challenges and so on. About the role of local government in controlling pandemic we found a very unique idea that is, legitimacy of the local government. Edward French (2011) wrote an article and elaborated the idea that controlling pandemic by local government initiatives must need acceptability of that local government. It requires public engagement and accountability to convince people about their policy about COVID-19 like social distancing. The literatures I have gone through had one short-coming that there are very a few researches on willingness. Willingness is somehow neglected by the researchers because they focused more on the effect of social distancing, not the issues which affect the willingness of the people. However, all these papers, materials and readings helped me to establish my own arguments.

\section{Method and Design}

This is a qualitative study with mixed approach which has been developed using both primary data and secondary sources. Primary data included the responses of the people; in this regard, an online population-based survey has been conducted with a semi-structured questionnaire among the people of Bangladesh from March 20 to August15, 2021. The questionnaire containing a total of 25 questions aimed to explore the understanding, perception and practice of the participants with regard to the implementation strategy of lockdown in Bangladesh. It also contained some open ended questions to understand public perception about the virus and social distancing measures. Participants were selected based on their profession, economic condition, sex, age, religion, political belief and educational qualification. They are Bureaucrats, Politicians, Pious men, poor working class, students and uneducated people (by help of others) and so on. In this method we can understand the character of variables which are working behind the mental construction of different clusters of people about social distancing in Bangladesh. 
It could raise the viability of this work if the number of respondents is extended. Face to face interviews could even be conducted. It could be random, on street, in offices, markets, religious institutions and so on. However, pandemic situation imposed strong barrier in this pursuit. The responses were collected using the Google Forms since the researcher stayed in the UK at the time of lockdown in Bangladesh and around. However, 225 participants sent back the filled-in forms.

Using google form was difficult to some respondents due to issues like internet accessibility, IT knowledge and interest in this research. The questions were taken and developed from different literatures about various widespread viruses and guidelines suggested by the World Health Organization (WHO). Questions were set which will help us to assess whether people are feeling 'over-confident' or not about the virus. People have been asked on Religion, political views, economic condition and 'willingness of social distancing' to find out if there is any correlation between them and to find out other factors. Moreover, during data analysis educational qualification of the respondents was considered. Primary data showed similarity with the secondary data which has already been mentioned in literacy review section. That helped to reach a smoother conclusion.

Data collection from respondents and a wide range of literature review contributed in this research based article. Multiple variable social distancing model proves to be the answer to this research which leads to find the answer of the question 'what are those factors which affect the human behavior towards social distancing?" People of different classes have different observation, thoughts and social experiences. 300 people were expected to respond, however 225 questionnaires have been sent back to the researcher. Respondents were comprised of 55 entry level bureaucrats, 20 senior bureaucrats, 15 religious and community leaders, 23 uneducated or semi educated people, 25 affluent individuals, 20 poor workers, 25 teachers, journalists and social workers, and 22 politicians. Among them 105 people were women participants. They have different responses. Simultaneously, literatures of different scholars have variety of arguments. Nevertheless, it is almost clear that everyone complied that 'willingness of social distancing' is a dependent variable which changes with social components like education, religion, confidence, credibility of the government, economic strength of people and so on.

Methodologically, this is a mixed type of research where qualitative data is used dominantly. Some Quantitative data and data analysis was figured with a view to getting the intensity of a qualitative data, to reach the authentic result. For instance, how many educated and uneducated people are interested about social distancing is a quantitative data but it provides a qualitative understanding that educated respondents are well aware about it. Age and sex sometimes have effect over human behavior regarding this policy of the government. So, classifying the respondents according to age, sex, profession, political belief or other types has contributed to this study finding out the relationship in between their 'willingness of social distancing' and 'influential social components'.

The overall research design has been sketched from two simple questions. "What makes people obey or disobey social distancing?" and "How the governments are considering the relationship between policy and policy responses?" A large literature review was required which included articles, news, journals and other secondary evidences. To get latest and more authentic data there is nothing better than interview or survey method by the researcher himself. Which lead this work to place a semi-structured questionnaire to variety of segments of people in Bangladesh. Young respondents are found relatively indifferent, callous and negligent. Aged, educated and female respondents have the exact opposite position. Scientists provided us with a temporary solution which is called social distancing but it depends on people whether they will obey it or not because it is related to human freedom, liberty, economy, religion, safety and so on. Finding chapter contains a table which will help us to understand how people responded with the questions and will provide us with a picture of social distancing policy and policy responses. These responses along with the references of secondary sources will pilot us to a new arena of policy thought, whereby we get the ultimate recommendation, 'the multiple variable social distancing model in reducing covid-19."

\section{Findings}

It is seen that in many countries, people violate social distancing norms because of their economic and social necessities (R Abouk, 2019). Sometimes they value their socio-political beliefs more than the risk of virus infection. In Bangladesh there are lots of evidences which show different factors affecting the practice of social distancing. Some specific factors are mentionable which provoke people disobey the social behavior prescribed by world health organization or other international organizations concerned with contagious diseases. These factors are economic condition, religious belief, public trust, over confidence, decentralization, policy transferability, corruption and educational qualification. Willingness of social distancing is not a constant variable rather it changes with the changes of other social factors. I consider willingness of social distancing as a dependent variable that depends on context and that context varies from country to country, even from place to place in a single country. 
Age, sex and education qualification can also affect the psychology of social distancing.

\subsection{Religious Belief}

Religious values influence public behavior connected with social distancing, specially Temple, Masque, funeral or other customary programs. Proper religious interpretation is considerably influential to make a change in human behavior regarding pandemic. Moreover, religious values have a strong impact on public attitude in Bangladesh. Newspapers reported that some of the religious leaders have publicly declared that this pandemic is a curse to some particular religion, or some particular religious people will enjoy immunity from their God (aa.com.tr, 2020).Shutting down masques, temples and other religious institutions is not as easy in Bangladesh as in the western countries. Here people must be completely convinced from the religious perspective if government wants to have a good response of a particular policy, or if government has scope to conduct study on policy implementation and religious values. Brahmanbaria, one of the biggest districts in Bangladesh has become notorious for violating social distancing norms mostly due to lacking the proper religious interpretation of contagious diseases like COVID-19 (Dhaka tribune, 2020). Local government bodies need to include religious leaders from different backgrounds and make them understand the threat of corona virus and convince them to explain it to people in a right way. Besides this, policy makers can be more aware about the religious values related to pandemic and contagious diseases to avoid unexpected grievance from the community. People in countries like Bangladesh, India and Pakistan can show negligence to social distancing norms due to misinterpretation of religious values or limitation of proper religious knowledge. During the first wave of COVID-19, misinterpretation of some religious leaders made uneducated people believe that this virus only comes for the non-Muslim criminals specially who stand against Islam. They started to believe good Muslims are not going to be affected by this virus and they stopped using mask and protective equipment, let alone social distancing. Some orthodox Hindus believed that cow dung and the urine of cow are good medicines against COVID-19. Thousands of Bengali and Indian Hindus were captured while drinking cow urine, media reported (The daily star, 2020). Government got the experience and included the religious leaders from different creeds, shut the prayer institutions and provided strong and straight guideline for them, and government successfully ensure the strong lockdown from 01.07.21 to 13.07.21 (The daily star, 2021). The same source also ensured that no gathering will be tolerated and Eid prayers will be arranged in a limited form. Government engaged the religious leaders and they ensured their cooperation and coordination.

\subsection{Economic Factor}

Poverty knows no law and makes people breach regulations. For example, while people are limiting community meeting and schools, colleges are closed, Markets are banning sellers and buyers to meet. Business growth falls down and people start to lose jobs. It has huge economic impact and poverty grows fast in countries like Bangladesh. People break social distancing, lock down, quarantine or other norms due to their livelihood, belief, context, and so on. Here, thousands of day-labor and garment workers came out of home when they are not supposed to do that, but they did it due to ensuring their next day meals (Bdnews24, 2021). Daily star (2020) reported that, people who are less educated, live in village and have low income are least willing to obey social distancing. This study aimed at some people from the working class specially with food and shopping mall business people. They stated emotionally, "We do not fear the corona virus, we fear the lockdown." (Dhaka tribune, 2021). Literature and newspaper provided enormous evidence that people belonging to lower middle class and lower class are unwilling to obey lockdown and some social distancing norms because they are suffering from poverty. Technically, when the crowd is big, they earn more. For instance, Street hawkers, footpath vendors, mobile shop vendors, drivers and helpers of local buses and small public vehicles have to earn their daily livelihood through interacting with people which has been practiced for ages. It is not easy to give this condition a proper shape within a very short time. Closing their business means debt, hunger and death. Social contacts are crucial for financial transactions. They need to go to work, rather than maintaining lock down and social distancing norms. Students should attend classes, buyers and sellers must meet. Social interactions are also sometimes unavoidable for people for non-financial activities, such as, for interacting with fellows and colleagues. Awareness of pandemic therefore engages each person in dilemma regarding personal choice between investing in social contacts and risking infection or, cutting social contacts and losing the social and economic benefits (Maharaj and kleczkowski, 2012). Poverty rate before corona pandemic was falling down due to the present government's initiative in digitizing services and boosting up non-government institutions. Industrial sector like readymade garments sector was contributing to eradicate poverty and hunger from the scene. Corona pandemic has turned the situation over and postponed all the development activities and export-import all of a sudden. It has cut the export immensely and pushed the factories into challenges. "Around \$3.18-billion-dollar order has been cancelled due to the trade disruption in the pandemic" (dw.com, 2020). Subsequently, Owners of the companies got bound to cut the number 
of workers and let them go workless. Among the employees, 80 percent are women. It played a vital role in women empowerment and proper distribution of wealth in society. Due to social distancing and lock down situation people faced joblessness.

Dhaka is a mega city with a massive income disparity among two billion people living in a single small zone. Laborers, street food vendors, small entrepreneurs, part time workers and so many diverse professions need nonstop effort and continuation. Social distancing, closure of public places, schools and other places have forced them sit idly. These have caused causes homelessness, joblessness and in some cases foodlessness. Hence, people under this situation do not honor the social distancing measures taken by the authority. They are opening markets, running transports, opening restaurants. Government in response to that has called for military support, but it did not work that much. Incentive package was announced by the Prime minister of Bangladesh in the mid of April which covers financial help to garments workers only. Other poor people are requested to get food supplies from the field level administration and the local government. Field level administration worked hard to ensure food supplies at the door of the poor (The Business Standard, 2020).However, local representatives and some officials have been accused of corruption in this incentive measure (The Business Standard, 2020). The Business Standard reported that "Corruption mars Bangladesh COVID 19 relief efforts.' It also informed that a few ruling party leaders and officials have been arrested during doing these kinds of corruptions. These issues have lot of impact of community sentiment. People get frustrated with government, feel deprived and become less willing to take social distancing initiatives. It makes people go outside, violate social distancing and carry on with other dangerous behavior.

\subsection{Education, Age and Gender Factors in Social Distancing}

Daily Prothom-alo (2020) has reported that uneducated people even sometimes the educated class fails to understand the meaning of lockdown, social distancing and isolation. These are new words in Bangladesh as it has not experienced contagious disease like COVID-19 in hundred years. Education and information plays a vital role in creating an environment where people can understand the value of changing behavior to be protected from being affected by corona virus. Research showed that in Denmark peoples' willingness is influenced by age, education and even gender differences. Professor Christian Germelmann (2020) showed in his research that symbols, and pictures have some roles in this behavior too. Being inspired from such works, I decided to contribute to the idea of willingness of social distancing and discussing the role of local government in Bangladesh. Respondents of my research were from different educational groups. I followed the same path which Professor Christian Germelmann walked on his research in Denmark. This study found $85 \%$ of educated people are enthusiastically supporting the lock down and social distancing policy of the government. And around $90 \%$ of uneducated people think this is a worthless approach and a policy of the government to suppress the opposition party. Young and energetic people think they are safer than others so they are more negligent than the others. Females are found to be more aware than the male individuals in the study. They support government lock down and social distancing policies and evidences showed that they are less accused of violating the regulations.

\subsection{Public Trust and Social Distancing}

In this study a trust paradox is discovered. Majority of Respondents think that information provided by the government is not authentic or genuine. Contrarily, Bureaucrat respondents stated that information are genuine. This makes a perplexing environment in decision making process and confuses the society as a whole. As mentioned earlier, since its independence Bangladesh has never experienced social distancing or similar kind of health measures, it is quite a novel idea which the educated sects of the society could understand fast, but uneducated and poor sects struggle to cope with (The Daily Star, 2020). Common people are fragmented into different types on the basis of their education, economy, religious affiliation and vulnerability. Willingness of social distancing varies based on these criteria. Naturally, Educated and urban people are found more conscious about this virus and its risk because of their education level. Contrarily, villages and uneducated people are relatively unwilling and unaware of social distancing measures. General perception among common people segregated because some people believed that Covid is a rumor. A group of people used to think this is not going to happen with very pious people, some were specific and confident about Muslims. At the very beginning, some doctors stated that corona virus is not working and affecting regions where temperature is over 23 degrees Celsius. A few newspapers also referred to particular researches and said that high humidity and temperature may reduce the spreading of COVID-19 (UNB, 2020), though this claim was not scientifically proved by WHO.A doctor, famous in social media, declared in Facebook account that this virus in not going to work in Bangladesh because temperature in Bangladesh is more than 28 degrees Celsius in summer. This video post has gone viral very fast. That statement made people feel better and safe. My assumption is that, behind the public negligence towards social distancing, this is one of the causes. 


\subsection{Integration and Coordination}

Parnab panday (2017) has noted in his writings that Bangladeshi local administration has been suffering from lack of proper integration and appropriate decentralization. Health department and other departments have complained that comparing to administration and police departments they are deprived of facility and security. There are enormous complaints about inter-departmental disharmony. To fight pandemics like COVID-19 it is extremely important that the departments have good understanding and coordination.

Government alerted people about COVID-19 but did not declare total lock down in the primary stage, rather sanctioned offered holidays or vacation. People went out for travel because they did not realize that that holidays was to stay home or to ensure social distancing. Later on,

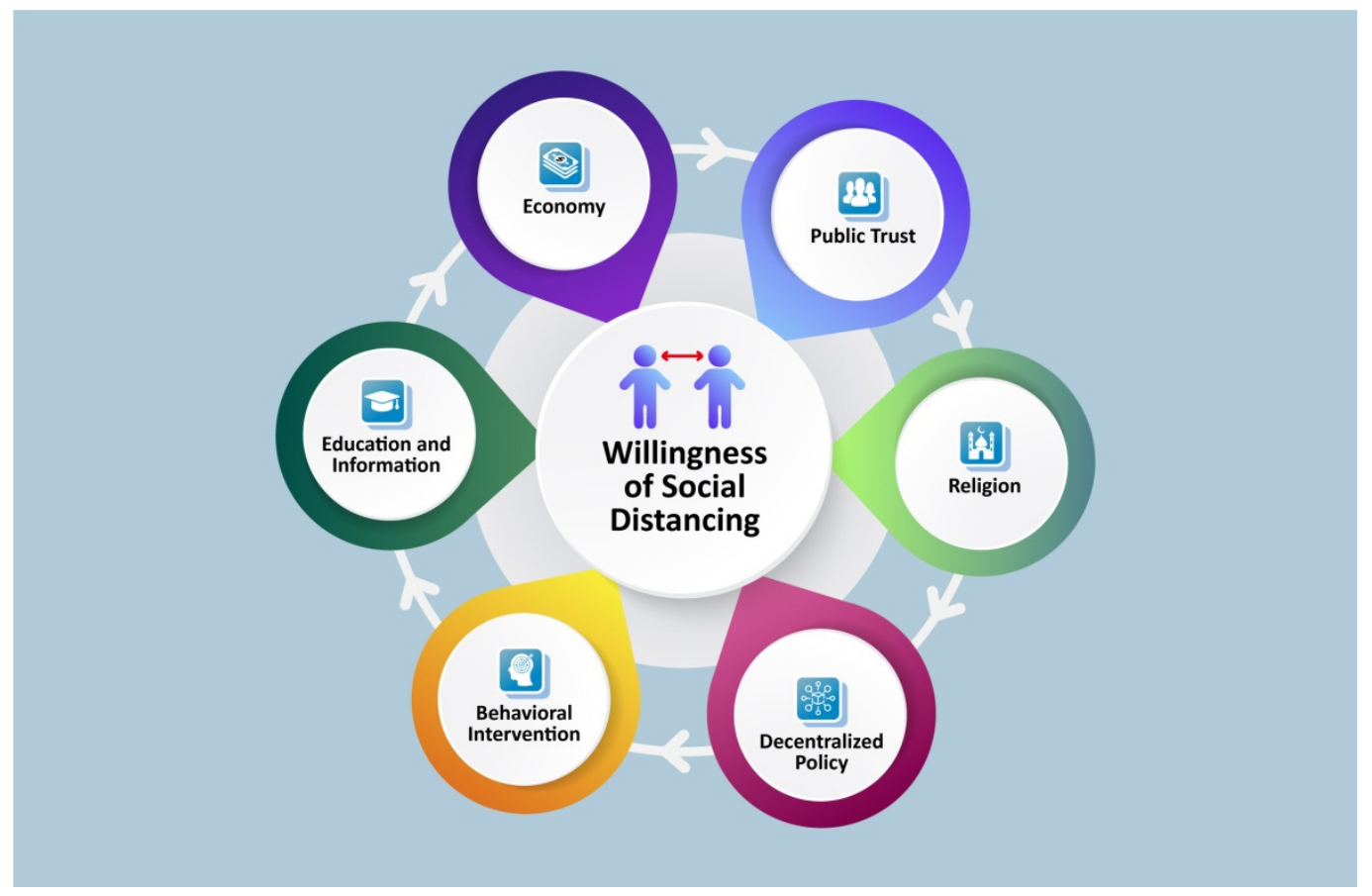

Figure 1. Variables those are influencing human behavior regarding social distancing policy

Government ordered to shut down business firms but garments sectors kept their factories opened and dragged their employees to the capital. At that time there was a restriction on transport business. So, Employees needed to walk the whole way making crowd and huge gathering. It was a hit on their social distancing sentiment.

Social distancing measure is a multi-tier approach where doctors test and isolate the patients; administration facilitates the working grounds initiating rules and laws; Police helps to force people who behave in a dangerous way. If departments do not work accordingly, common people will be misguided, frustrated and they will be less interested about the social distancing strategies; their willingness of social distancing will decrease. In any disaster or pandemic, the officers of administration cadre come forward first with the collaboration of Bangladesh police and other related departments, in both policy generating and initiating. Other officers, who are not directly concerned, are found less enthusiastic and less dutiful towards tackling those hazards. This does not mean that those officers are not qualified or trained enough; rather it sketches the picture that there must be something wrong whereby other officers are not that motivated like administration or police. There is another question, why everyone should take pressure? Or the work distribution can be revised one more time. Who is to do what and who will oversee whom, must be specific. Administration cadre officers are playing the role of coordination and overseeing into matters historically but there are complaints of lack of proper coordination among departments in tackling the COVID-19 situation. Police is also misusing their power during lock down, reports have repeatedly said. On the other hand, doctors are becoming frustrated of treating additional number of patients with their very limited number of equipment.

In United Kingdom, the local NHS has enough budgets itself and the local government can spend money by itself for local health development, Bangladesh lacks this approach. Community health clinics, and local hospitals get the budget allocation from the central government and the local government has no such power to spend money 
for making new beds, purchasing ventilators or oxygen in case of emergency. During this pandemic, countries needed additional number of hospitals, additional number of beds and equipment. Some countries enhanced the number of sits and beds with required materials using their local funds, whereas some countries failed.

\section{Discussion and Recommendation}

As Galea (2020) has mentioned, COVID-19 fighting strategy should be based on local context, this paper is going to suggest a very context-based model for Bangladesh. We can name it "multiple variable social distancing model." There are a number of variables working behind willingness of social distancing in Bangladesh. From the discussion above we have had a picture what is happening with social distancing relating to a bunch of factors. Two factors which we can discuss together are economic condition and the behavioral intervention of the government. International and national newspapers reported that after lock down Bangladesh will have 30 percent of its labor unemployed. Government tried to provide food and other supplies which are not enough for the long shut down. To survive, people are bound come out of home. They do not have enough money to buy one-time masks and sanitizer. Such poor condition makes them dishonor the social distancing policies. Scholars like Bhuyan, sakib, Pakpour, Griffiths and Mamun (2020) have showed that many poor people committed suicide due to poverty. They illustrated 8 notable suicide cases from different areas of Bangladesh. The victims were from the poor community, such as day-laborer, rickshaw puller and restaurant workers. Government has tried it's best to protect them from hurting themselves and served them with food and money. However, the size of poverty in countries like Bangladesh and India is so big that they cannot ensure appropriate compensation and other necessary supplies at the same time. These countries need international grant and cooperation. When other people say that the people of Bangladesh are not obeying the social distancing norms and blame them for being ridiculous, it sounds like they are not civilized human. The reality is they are civilized with less education and resources. Under this situation we need to make a long-term plan which will help countries like Bangladesh in the upcoming pandemic, when nonpharmaceutic solution is a must.

Now it will be effective to show some glances of primary data and to evaluate what the respondents expressed as a whole. To be very specific, respondents' position and feedbacks should be clearer than the design chapter.

\begin{tabular}{|c|c|c|c|}
\hline Groups of respondents & Number of respondents & $\begin{array}{l}\text { Positive and respectful to } \\
\text { social distancing policy }\end{array}$ & $\begin{array}{l}\text { Negative and pessimistic } \\
\text { towards social distancing } \\
\text { policy }\end{array}$ \\
\hline Age above 40 & 92 & 74 & 18 \\
\hline Age bellow 40 & 133 & 67 & 66 \\
\hline Affluent & 25 & 20 & 05 \\
\hline Poor and uneducated & 20 & 06 & 14 \\
\hline Male & 120 & 70 & 50 \\
\hline Female & 105 & 87 & 18 \\
\hline Ruling party & 12 & 11 & 1 \\
\hline Opposition party & 10 & 3 & 7 \\
\hline $\begin{array}{l}\text { Religious and community } \\
\text { leaders }\end{array}$ & 20 & 7 & 13 \\
\hline $\begin{array}{l}\text { Liberal educated } \\
\text { (Teachers, social workers, } \\
\text { journalists) }\end{array}$ & 25 & 23 & 2 \\
\hline Government employee & 70 & 60 & 10 \\
\hline Businessmen and others & 140 & 47 & 93 \\
\hline
\end{tabular}

They have responded from the perspective of their location, position, education, bias and economic condition. For instance, Entry level bureaucrats who are implementing policies under senior officers think that this is too difficult to make people obey the social distancing policies whereas senior bureaucrats think making people understand and obey is not that problematic if there is proper coordination in the field level offices. Among the religious community there is a distinct type of responses. Among the 8 Muslims every one of them believe that Covid-19 is 
a curse from Allah and he will save the Muslims. Respondents apart from Muslims have almost the same stand. They think their respective Gods will save them, and if God wants to smash this civilization no policy and medicine can save the world. So they don't even think it is important to shut schools or business. Affluent and educated people emphasized on lockdown, social distancing and public health rather than economy or religious beliefs. However, political belief has a strong role in making willingness or social distancing.

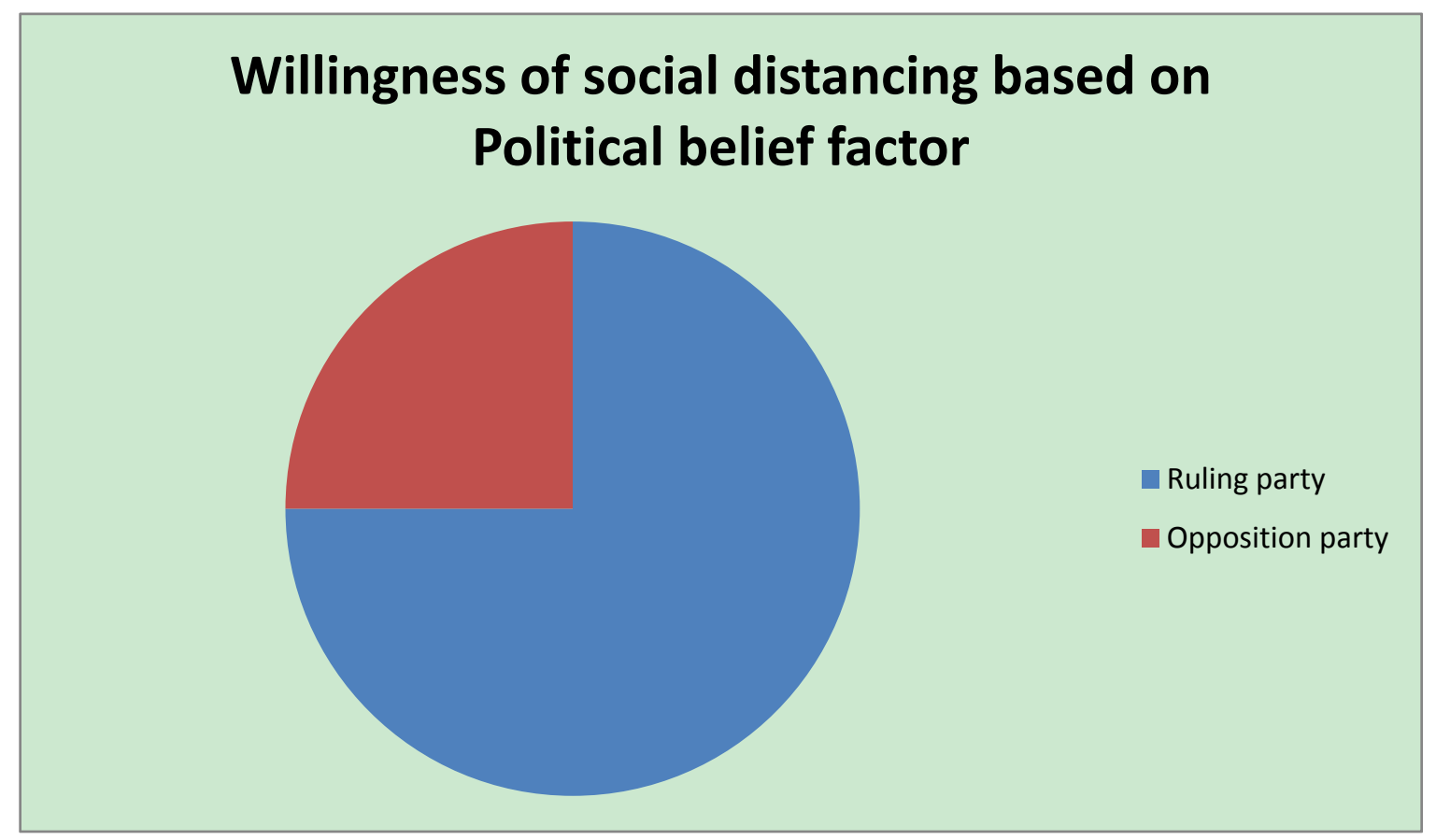

Figure 2. 22 political persons sent the questionnaire back that has a politically biased perspective towards the social distancing policy initiatives by the government. Ruling party people are more willing and opposite party people are less willing to social distancing policy initiatives

Source: Primary data.

12 ruling party members who responded think that some opposition party members are trying to disseminate rumors, making chaos and other social issues to blame this government with a failure, as a result people are being disrespectful to the social distancing policies. On the other hand opposition party members believe that social distancing policies are very important but this government has failed to make a correlation among departments and government is using this pandemic for their own benefit. Almost every one of them is dissatisfied with present government policy. Additionally, both the party members think local government should have more administrative and budgetary power to play independently. Regarding the age factor, young people are found callous, indifferent and over-confident. Among 20 young students 18 think that covid-19 is not going to affect them badly. 


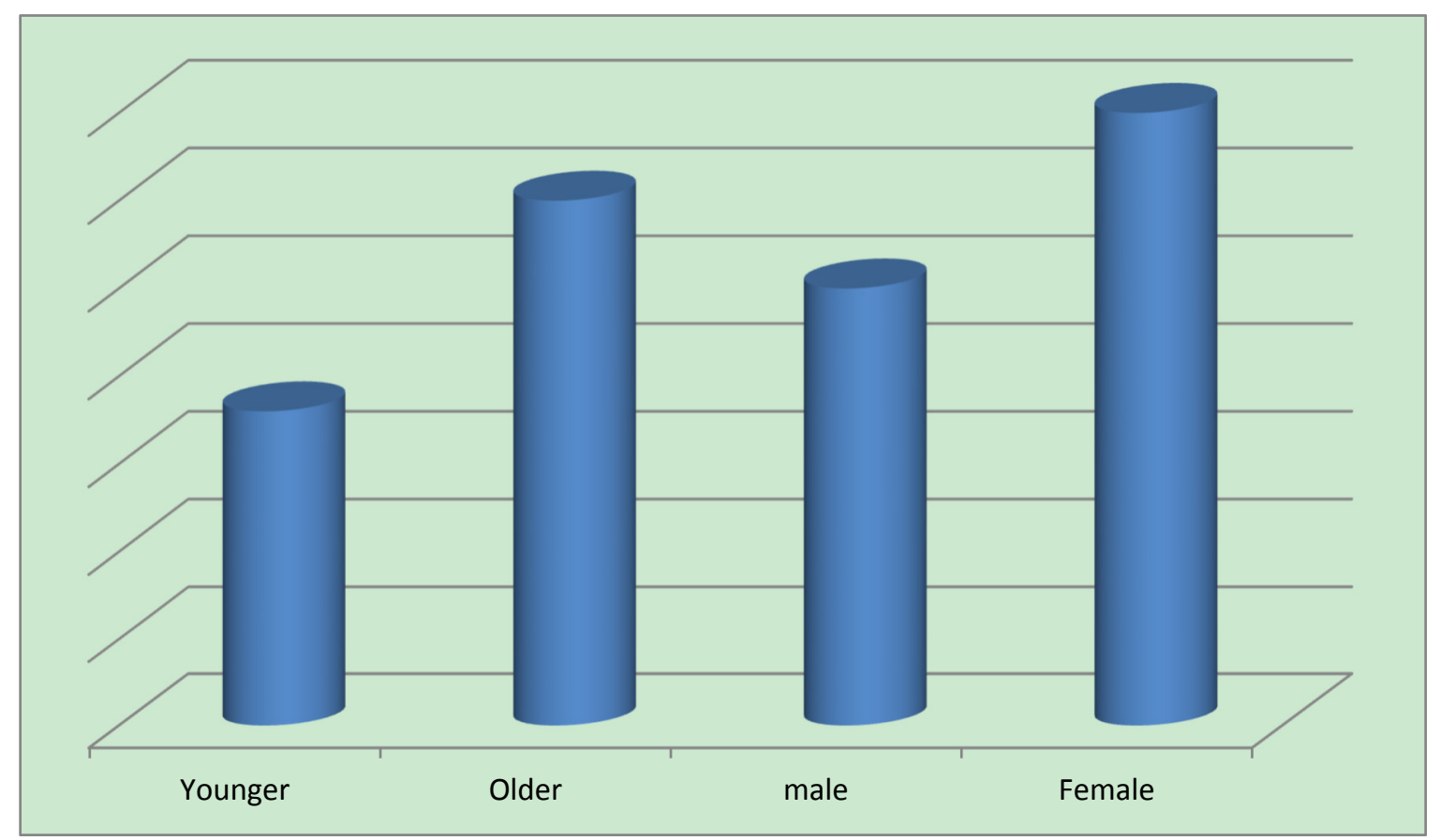

Figure 3. Comparative willingness of different group of respondents. The high the bar, the more they are enthusiastic to the social distancing policy taken by the government of Bangladesh. Data is shown out of 100 percent. For each horizontal line 10 percent increases.

Source: Primary data.

They think they have enough immunity to tackle the virus; however they are little concern about spreading disease and security of others who are living around them. Government employees supported complete shutdown and compulsory and punishable measures whereas producers and sellers want them to be relaxed as possible. Females are found more responsive to the government policies. They mentioned that they have children to look after. Moreover women are usually the meal maker of the house so they need to be clean and sanitized. They support using mask, sanitization, lockdown and closure of schools and other government initiatives. 


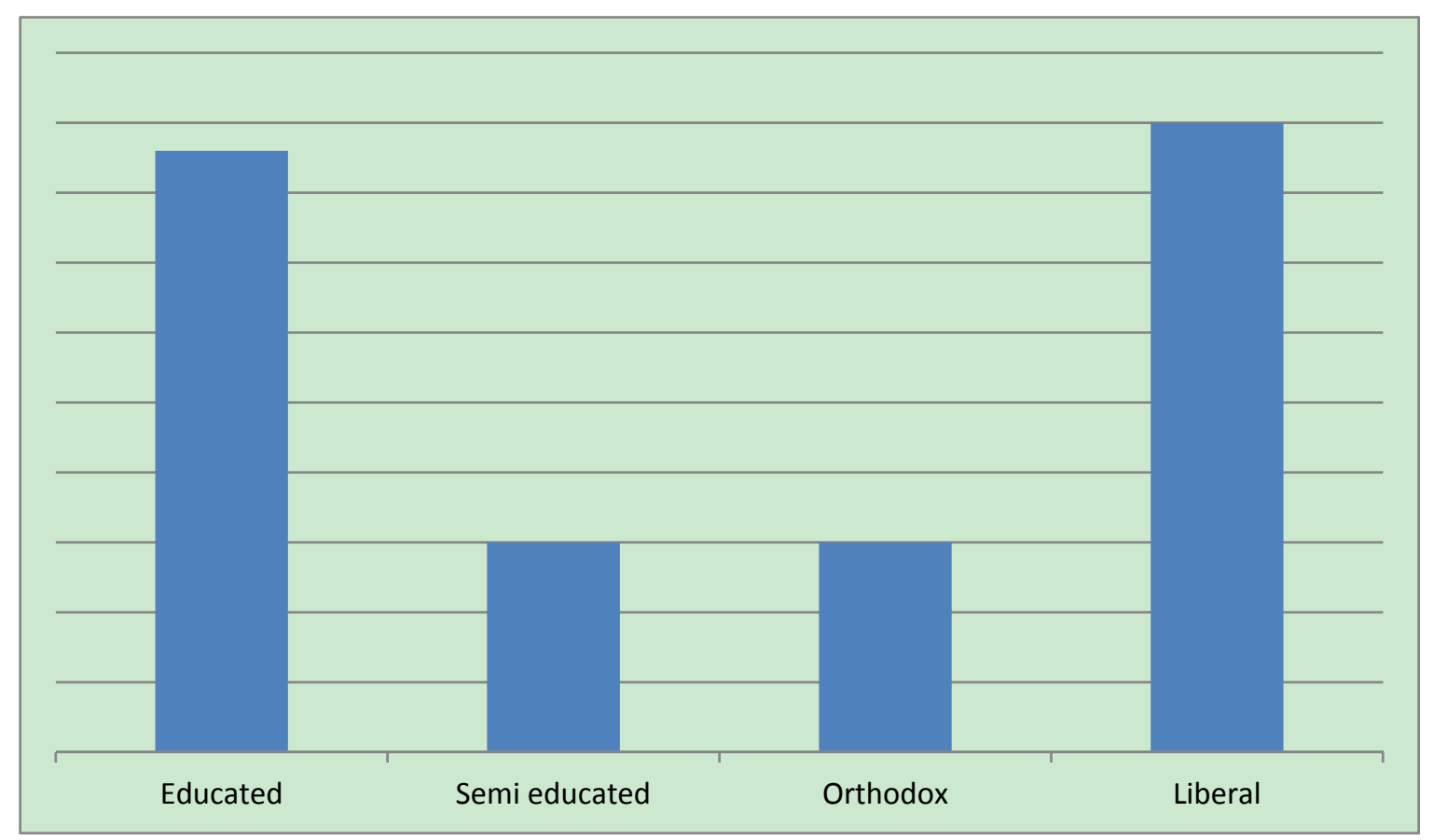

Figure 4. Comparative willingness of different group of respondents. The high the bar, the more they are enthusiastic to the social distancing policy taken by the government of Bangladesh. Data is shown out of 100 percent. For each horizontal line 10 percent increases.

Source: Primary data.

Primarily, 'multiple variable model' works in an inclusive method where people, government, situations, instruments and beliefs have been taken into consideration. It does not expect orders and responses only. Rather, it works with values, laws and the grounds where the laws are implemented. It justifies why and how laws are breached. In the case of willingness of social distancing in countries like Bangladesh, it is expected to work as the discussion bellow.

In multiple variable model there may have a domino effect among the variables. This domino effect can push a positive force in enhancing willingness of social distancing in Bangladesh. For instance, to ensure the long-term social distancing measure we need a group of educated people. We have to include some lessons in the school text which will help the teachers and students both to work for the society. Young and male people should be included in awareness program. Local governments can establish a permanent volunteer group which will conduct research on crisis management. This may lift up the general awareness and understanding level of the people. Policy makers can get wider feedback of their policies too. Besides that, we need to work for the development of public trust. To achieve this goal government needs to control corruption specially related to relief and health care. Purchasing of masks, sanitizer, and ventilation should be open and available through e-tendering system. Distribution of relief for the poor must follow specific record management system which will help to identify who is to get and who has received the relief products. To enhance public trust peoples' representative has to act with the highest responsibility. They should publish the genuine data of COVID-19 test. False result, fake COVID statement and limited number of test can frustrate people towards the government initiatives. Genuine reports will depict the real scenario of the existing situation and facilitate public decision. Disclosure of right information is always appreciated to lift up public trust, in the COVID state of 'fear versus negligence' it plays an influential role. It helps people when to fear and when to not neglect the virus. This ultimately ameliorates trust to the government.

Another probable solution is providing genuine and logical religious interpretation. Countries like Bangladesh, India and Pakistan have included lots of religious values and customs into their laws. A large number of people dare to supersede state law based on customs and explanations from the religious leaders. These explanations sometimes justify the violation of state laws because religious leaders play a hypnotizing role in the society. Regarding the closure of temple, mosques and other prayer places Bangladesh, India and Pakistan faced the same problem (Dhaka Tribune, 2020). If the central government includes the national level educated religious leaders 
in making policies, and local government in implementing them, people who are blindly follow religious interpretations can be benefitted. It is even written in Islam that during pandemic no one can get in or out of the area affected. Proper interpretation helped people avoid dangerous behavior in the past. As yoval noa harari said in his book 21 lessons for $21^{\text {st }}$ century that, "religions do not fight against the dangers alone. Now, we have to pray but we have to see the doctor" (Harari, 2012). We have to memorize verses from holy books staying inside and obeying social distancing. World Health Organization has published a paper titled "Religion and Faith Community" and suggested that religious leaders have many things to do to control the spreading. It recommends restrictions for common people in prayer places and maintain highest level of hygiene in such areas. Including faith, people in policy making and decision taking process can be wildly appreciated and accepted (WHO, 2020).

Like those variables mentioned above, this model suggests limiting the 'over-confidence', boosting up economic compensation and initiating decentralization process. Regarding overconfidence of the people, it is seen that young aged people are more enthusiastic in violating social distancing norms because the statistics show that they suffer less and die less. However, they need to understand that they can be the medium of the spreading. This model suggests a local community-based action group. It will oversee and monitor every single house with the help of local government. They must be provided with genuine information and statistics to make them aware. Additionally, people will be provided with some pictures and videos of sufferings to initiate a nudge. To this study, awareness comes from slight amount of fear. Over-confident people risk their lives more than the frightened and cautious group. Apart from this variable, multiple variable social distancing model suggests to ensure practical economic compensation programs. Supplementation of food by political party and local administration in such a populous country makes the situation more complicated. It is better to send money via mobile banking, or local government office. It needs a citizen data base and income record. In UK local government can easily check the works department record to check the employability of a citizen, in Bangladesh they do not. For facing challenges like pandemic and disaster we need a permanent employability data base. So, I suggest making a good quality data sharing between local governments, works department and companies or employers of the country. In this pandemic time government needs every single data about the victims and the sufferers. It will help cut corruption and grow public trust. To enhance the willingness of social distancing government has taken some coercive measures too. For example, penalize people who do not wear mask, unwilling to maintain social distancing and commit any kind of fraudulent acts evolving the pandemic situation. Such strong stand against fraudulent acts can pull the public trust towards government to a stable position. Government officials are monitoring the public places every now and then, executive magistrates are running mobile court to alert people and make them legally bound to obey the social distancing rules for the collective welfare. In short term, coerciveness is a factor which may change the choice option of the people.

One more important feature can be mentioned and referred to which is related to the social distancing norms. Statista is a world renowned organization for conducting survey and research. It mentioned that 'Time period' in social distancing is an important factor that can contribute in changing human behavior. If the lock down and closure approach runs for long, people loses their patience to stay at home, wear mask and avoiding crowd. Rather, they look for gathering, sharing foods, hugging each other. Government should ensure maximum vaccination to prove that it is not just depending on non-pharmaceutic solution, rather seeking for medical responses as well. As we are saying that the second wave has come which means we have had the first wave. What are we doing to protect ourselves from the second wave? What we will do if it has third, fourth or fifth waves too? Multiple social distancing model is a sustainable social distancing context-based model which can include more factors depending on situation, lessons and necessity. The invention of Vaccine does not guarantee that no more pandemic will hit us in future. We must have a term social distancing policy and model if we want to lead a happy and safe life.

\section{Conclusion}

Willingness of social distancing fluctuates with the changes of factors, variables and their impact on the human mind. From the COVID-19 pandemic we have had a good number of lessons that can prepare us better for the next examination, next pandemic. We are not so sure that human civilization is experiencing the last pandemic in the history. Future must have some more shocks and they are waiting for us which will strongly require our behavioral changes and non-pharmaceutic solutions. For that coming moment we have to unwrap our learnings from this contagion. Time will change, factors and catalysts will modify too. Finding out the variables and put proper importance upon them will be another new challenge. Economy, religion, Over-confidence, Education may be replaced by information communication and technology, use of artificial intelligence, level of pollution, political condition and so on. Behavioral change and change in choice structure definitely need to correlate with all inclined ideas and issues that may have an impact.

What happened in past is not just gone, it will come in a new form. What we learnt is not to store in our brain only, 
it is to reshape and reuse. COVID-19 pandemic has not finished its teaching yet, though the vaccine has come, still it continues its life taking attack on humankind. Multiple social distancing model considers variables on the basis of place, time and context. Variables vary from place to place, time to time. We must make our policies analyzing variables, their connectivity and initiate our policies and check the effectiveness. Countries like Bangladesh has more challenges due to a large number of populations, diversity, lack of education, poverty and climate vulnerability.

Working with the government of Bangladesh for the last five years has made me realize/experience that, In Bangladesh, central government is responsible for policy making and field level bureaucrats implement those policies. Social distancing is a policy which is mostly implemented by the local administration and political leaders. From different kind of sources, we know and understand that people are losing interest from social distancing in long term. Substantially the main goal of this paper is to find what makes people disobey or obey the social distancing norms here in countries like Bangladesh and to suggest the central and local administration to take necessary initiative accordingly. We have to be very keen to the public response about any policy. If we think that government takes policies and people will blindly obey, this idea does not work in the real world. Human brain finds some short-cut to take a decision, they want liberty. It depends on heuristics and biases which do not let them think more scientifically. Policy makers need to take and implement policies which can be accepted and followed consciously, at least most of the time.

Poor people who need to work every day to earn their daily meal do not want to stay home. It is an economic factor which forces them to violate the social distancing norms (Maharaj and kleczkowski, 2012). Government took relief initiatives to support the poor. It motivates them to stay home for some days. Satisfaction had blown away when people heard about corruption in relief program and they felt deprived subsequently. It had a negative impact on public trust. Public trust has been at the edge when media published that a number of hospitals are providing paid and fake COVID-19 report in demand. When people see lot of fake things around them it makes them frustrated and unruly. Local administration must control the corruption in given areas. Internationally there are evidences that different countries are following different ways for social distancing. They are using technologies and information data base. Such kind of data integration, contact tracing apps can be introduced in Bangladesh too. To do so, local officials must be more open to innovation. Multiple variable social distancing model can help countries like Bangladesh work in different cultures, layers and groups of the society. People in Bangladesh are mostly pious and strong believers. This is good but sometimes it makes a better way for rumor. Government has to prevent this by engaging some religious scholars in policy making process. Economy, religion, over-confidence, education, coerciveness, age, sex all these factors, if considered accordingly while making policy, people might be more interested in social distancing. It is a comprehensive and inclusive approach. Each and every variable should be taken care of and further research is required to find out if there are any other variables behind this policy in a particular social setting.

\section{References}

aa.com.tr. (2020). Bangladesh: Massive funeral for elecric amid lockdown. Retrieved April7, 2021, from https://bdnews24.com/bangladesh/2021/04/06/workers-suffering-for-transport-ban-marks-beginning-oflacklustre-bangladesh-lockdown

Ahn. (2020). How South Korea flattened the corona virus curve using technology. Retrieved July 29, 2020, from https://www.preventionweb.net/news/view/71406

Baker. (2020). Corona virus disrupts deal severe blow to Bangladesh's Garments industry. Retrieved July 2, 2020, fromhttps://www.dw.com/en/coronavirus-disruptions-deal-severe-blow-to-bangladeshs-garment-industry/a53895339

BBC. (2020). Corona virus: Government to pay up to $80 \%$ of worker's wage. Retrieved July 10, 2020, from https://www.bbc.com/news/business-51982005

Bdnews24. (2021). Workers' suffering for transport ban marks beginning of lacklustre Bangladesh lockdown. Retrieved April 18, 2021, fromhttps://bdnews24.com/bangladesh/2021/04/06/workers-suffering-fortransport-ban-marks-beginning-of-lacklustre-bangladesh-lockdown

Bhattacharjee. (2021). The republic of Bureaucrats, The daily star, Dhaka. Retrieved July 24, 2021, from https://www.thedailystar.net/frontpage/news/the-republic-bureaucrats-2110361

Bhuyan et al. (2020). COVID-19-Related Suicides in Bangladesh Due to Lockdown and Economic Factors: Case Study Evidence from Media Reports, NCBI. https://doi.org/10.1007/s11469-020-00307-y

Bhuyan, S., \& Mamun. (2020). COVID-19 related suicides in Bangladesh due to lock down and economic factors: 
case study evidence from media reports. International journal of mental health and addiction. https://doi.org/10.1007/s11469-020-00307-y

Chung, Y.-L. (2020). Social reaction toward the 2019 coronavirus (COVID-19). Social health behavior journal, 3, 1-2. https://doi.org/10.4103/SHB.SHB_11_20

Dhaka tribune. (2020). Regent Hospital scam: Shahed a listed fraudster, absconding for four days. Retrieved April 19, 2021, fromhttps:/www.dhakatribune.com/bangladesh/2020/07/11/regent-hospital-scam-shahed-a-listedfraudster-absconding-for-four-days

Endow. (2020). Singapore and social distancing. Retrieved August 5, 2020, from https://www.biophysics.org/blog/singapore-and-social-distancing

Faisal, M. (2020). Corna virus: in dense Bangladesh, social distancing a tough task. Al jajeera/news/Bangladesg. Retrieved June 19, 2020, fromwww.aljazeera.com/amp/news/2020/03/coronavirus-dense-bangladesh-socialdistancing-tough-task-200320103733470html

Fenichel, E. (2013). Economic consideration for social distancing and behavioral based policies during epidemic. Journal of health economics, 32, 440-451. https://doi.org/10.1016/j.jhealeco.2013.01.002

Flush. (2020). Isolate isolate and isolate: China's approach to COVID 19, quarantine could be the most effective. Retrieved July 10, 2020, from https://www.telegraph.co.uk/global-health/science-and-disease/isolate-isolateisolate-chinas-approach-COVID-19-quarantine/

Fox news. (2020). Bangladeshi funeral attracts 100000 people shattering coronavirus social distancing rules. Retrieved July 24, 2020, from https://www.foxnews.com/world/100000-attend-bangladesh-funeralshattering-social-distance-protocols

Galea. (2020). China shows COVID-19 responses must be tailored to the local context. Retrieved July 8, 2020, from https://www.euro.who.int/en/health-topics/health-emergencies/coronavirus-COVID19/news/news/2020/4/china-shows-COVID-19-responses-must-be-tailored-to-the-localcontext\#: :text=China's\%20first\%20phase\%20of\%20public,over\%20the\%20long\%20term

Germelmann. (2020). How nudging can help ensuring social distancing. University of Bayreuth. Retrieved July 13, 2020, from https://www.uni-bayreuth.de/en/university/press/press-releases/2020/086-expert-interviewgermelmann-nudging-social-distancing/index.html

Human rights dimension of COVID-19. (2020). Human rights watch. https://doi.org/10.1080/14754835.2019.1671178

Interim guidance, WHO. (2020). Practical considerations and recommendations for religious leaders and faithbased communities in the context of COVID-19. Retrieved April20, 2021, from https:/www.who.int/publications/i/item/practical-considerations-and-recommendations-for-religiousleaders-and-faith-based-communities-in-the-context-ofCOVID19?gclid=Cj0KCQjw1PSDBhDbARIsAPeTqreLAFnpvIK61XJ9MCzx3Myu0V4plw4f7JWvnnuleb QwJ7MD10-j08AaAlgJEALw_wcB

Islam, T., \& Siddique. (2020). Tackling the pandemic COVID-19: The Bangladesh perspective, Preprints. https://doi.org/10.20944/preprints202004.0384.v1

Kahneman, D. (2011). Thinking, Fast \& Slow, New York, straus and Giroux.

Kamruzzaman. (2020). Bangladesh: thousands gather in masques amid pandemic. Retrieved July 24, 2020, from https://www.aa.com.tr/en/asia-pacific/bangladesh-thousands-gather-at-mosques-amid-pandemic/1833947

Kissler, Tedijanto, Lipsitch, \& Grad. (2020). Social distancing strategies for curbing the COVID-19 epidemic, medxriv. https://doi.org/10.1101/2020.03.22.20041079

Kozlowski, Kiviniemi, \& Ram. (2010). Esier said than done: Behavioral conflicts in following social distancing recommendations for influencza prevention. Public health report, 125(6), 789-792. https://doi.org/10.1177/003335491012500605

Maharaj, \& Cleczkowski. (2012). Controlling epidemic spread by social distancing: do it well or not at all, BMC public health. https://doi.org/10.1186/1471-2458-12-679

Moore, \& Healy. (2008). The trouble with overconfidence, Psychological review. American psychological association, 115(2), 502-517. https://doi.org/10.1037/0033-295X.115.2.502

OP-ED: What we fear is not the lockdown, Dhakat tribune. (2021). Retrieved July 18, 2021, from 
https://www.dhakatribune.com/opinion/op-ed/2021/04/16/op-ed-what-we-fear-is-not-the-lockdown

Painter, \& Qui. (2020). Political beliefs affect compliances with COVID 19 social distancing orders. https://doi.org/10.2139/ssrn.3569098

Parnab panday. (2017). Decentralization without decentralization: Bangladesh's failed attempt to transfer power from central to local governments. Asia pacific journal of public administration, 39, 177-188. https://doi.org/10.1080/23276665.2017.1363940

PSGT. (2020). Coronavirus government response tracker. Retrieved July 28, 2020, from https://www.bsg.ox.ac.uk/research/research-projects/coronavirus-government-response-tracker

Rahman. (2020). Physical Distancing with Mental Health Services during COVID-19 in Bangladesh. Retrieved July 4, 2020, fromhttps://www.annfammed.org/content/physical-distancing-mental-health-services-duringCOVID-19-bangladesh

Rahi Abouk. (2019). The Immediate Effect of COVID-19 Policies on Social-Distancing Behavior in the United States. Public health reports, 136(2). https://doi.org/10.1101/2020.04.07.20057356

Rama chandran. (2020). The COVID 19 catastrophe in Bangladesh. Retrieved August 1, 2020, fromhttps://thediplomat.com/2020/04/the-COVID-19-catastrophe-in-bangladesh/

Reluga, C. (2010). Game theory of social distancing in response to an epidemic. PloS computational biology, 6(5). https://doi.org/10.1371/journal.pcbi.1000793

Sakid, \& Rahman. (2020).Local solutions for the local COVID 19 problems: community activism in Bangladesh. Retrieved July 4, 2020, from https://blogs.lse.ac.uk/southasia/2020/05/20/local-solutions-for-local-COVID19-problems-community-activism-in-bangladesh/

Slate.com. (2020). How to Use Psychology to Convince People to Take Social Distancing Seriously. Retrieved fromhttps://slate.com/technology/2020/03/coronavirus-social-norms-psychology.html

Statista. (2020). Willingness to coronavirus social distancing and behavior rules in the Netherlands in the 2020, by length of duration. Retrieved July 4, 2020, from https://www.statista.com/statistics/1115773/dutchwillingness-coronavirus-rules-compliance/

The daily star, 13 July 21, Lockdown to ease before Eid. Retrieved July 18, 2021, fromhttps://www.thedailystar.net/health/disease/coronavirus/news/lockdown-ease-eid-2128471

The daily star. (2020). Social Distancing: Only a quarter practiced it: Finds a DGHS survey on 1,549 people in March-April. Retrieved April 18, 2021, from https://www.thedailystar.net/frontpage/news/social-distancingonly-quarter-practised-it-1952161,Last

The daily star. (2021). Indian doctors warn against cow dung as COVID-19 cure. Retrieved July24, 2021, from https://www.thedailystar.net/coronavirus-deadly-new-threat/news/indian-doctors-warn-against-cow-dungCOVID-19-cure-2091885

UCA news. (2020). Corruption mars COVID 19 relief effort. Retrieved April16, 2021, from https://www.ucanews.com/news/corruption-mars-bangladeshs-COVID-19-relief-efforts/87700

\section{Copyrights}

Copyright for this articleis retained by the author(s), with first publication rights granted to the journal.

This is an open-access article distributed under the terms and conditions of the CreativeCommons Attribution license (http://creativecommons.org/licenses/by/4.0/). 